\title{
Virginia Apgar (1909-1974): Neurological Evaluation of the Newborn Infant
}

\author{
J.M.S. Pearce \\ Emeritus Consultant Neurologist, Department of Neurology, Hull Royal Infirmary, Hull, UK
}

Neurologists often are asked to advise about epilepsy, infant and childhood cerebral handicap, their aetiology, treatment and prognosis. A crucial factor in assessment has been the Apgar score to assess the neonatal condition that may be relevant to later neurological damage. Dr. Apgar developed the 10-point scoring system (table 1) in 1952 to focus attention on neonates in the first critically precarious minutes of life. A low score immediately signalled the need for emergency attention.

\section{Virginia Apgar}

Virginia Apgar was born in 1909 in Westfield, N.J., USA. Her father, a scientist, wrote several papers on the moons of Jupiter, and excited Virginia's interest in sci- ence. At a time when few women even attended college [1], she was determined to be a doctor [2].

In September 1929, she entered the College of Physicians and Surgeons at Columbia University. In dire financial difficulties at the time of the stock market crash, Apgar had to borrow money from family friends. She graduated in 1933, fourth in her class, a member of Alpha Omega Alpha Society, and nearly $\$ 4,000$ in debt [2].

She won a prized surgical internship at Columbia [3], where she performed brilliantly. But Alan Whipple, chairman of surgery, discouraged her because so many women surgeons had failed to succeed financially in a male-dominated specialty that was competitive and overcrowded [3]. Whipple, recognising her ability, persuaded her to train in anaesthesiology, then often performed by nurses.

Table 1. Apgar score for newborns

\begin{tabular}{lllll}
\hline & Sign & 0 points & 1 point & 2 points \\
\hline A & $\begin{array}{l}\text { Appearance } \\
\text { (skin colour) }\end{array}$ & $\begin{array}{l}\text { blue-grey, } \\
\text { pale all over } \\
\text { absent } \\
\text { no response }\end{array}$ & $\begin{array}{l}\text { normal except for } \\
\text { extremities } \\
\text { below 100 bpm } \\
\text { grimace }\end{array}$ & $\begin{array}{l}\text { normal over entire body } \\
\text { above 100 bpm } \\
\text { sneeze, cough, pulls } \\
\text { away }\end{array}$ \\
$\begin{array}{llll}\text { Pulse } \\
\text { Grimace } \\
\text { (reflex irritability) }\end{array}$ & $\begin{array}{l}\text { absent } \\
\text { Activity }\end{array}$ & arms and legs flexed movement \\
(muscle tone) & absent & slow, irregular & good, crying \\
\hline
\end{tabular}

Joseph Butterfield used the letters of her name as an acronym.

\section{KARGER}

Fax +41613061234 E-Mail karger@karger.ch www.karger.com
(C) 2005 S. Karger AG, Basel 0014-3022/05/0543-0132\$22.00/0

Accessible online at:

www.karger.com/ene
J.M.S. Pearce

304 Beverley Road

Anlaby, East Yorks HU10 7BG (UK) 


\section{Anaesthesia}

She arrived in Madison, Wisc., and from 1937 to 1938 was a resident with two of the fathers of American anaesthesiology, Ralph Waters at Wisconsin, and Emory Rovenstine at Bellevue Hospital, New York. She surmounted considerable housing and professional difficulties, to return to Columbia as Director of the Division of Anaesthesia in 1938. There she faced a huge clinical workload and a reluctance by surgeons to accept anaesthetists as their equals [4]. She was the only staff member until 1940, when Dr. Ellen Foot, one of the residents, joined her. The clinical work increased when colleagues left for the armed services. But many later returned from World War II to anaesthetics and in 1945 for the first time, more anaesthetics were given by doctors than by nurses. However, a major row developed because anaesthetists were not allowed to charge professional fees; Apgar threatened to resign: the conflict was resolved.

After World War II, staffing recruitment improved and anaesthesia became better recognized. In 1949, Emmanuel Papper, a Bellevue anaesthetist with a research background, was made head of the division and 6 months later both Apgar and Papper were appointed professors, making her the first woman professor at Columbia.

\section{The Apgar Score}

She then entered a new phase of obstetric anaesthesia yielding her most important contribution. The idea came in 1949, when over breakfast a medical student highlighted the need to evaluate the newborn. Apgar said, 'That's easy! You'd do it this way.' She picked up the nearest piece of paper and wrote down the five points of the Apgar score. She proceeded to appraise anaesthesia records of 1,025 infants, rated by her score. The score was presented in 1952 at a meeting, and published [5] in 1953. It has stood the test of time [6]. Its aim was

'to establish a simple and clear classification of newborn infants which can be used to compare the results of obstetric practices, types of maternal pain relief and the results of resuscitation'.

At first the score was measured $60 \mathrm{~s}$ after birth, to guide the need for resuscitation. Correlating the 60 -second score with neonatal mortality, infants receiving 0,1 or 2 scores had a neonatal death rate of $14 \%$; those scoring $3-7$ had a death rate of $1.1 \%$; and those scoring $8-10$ had a death rate of $0.13 \%$. She concluded: 'the prognosis of an infant is excellent if he receives one of the upper three scores, and poor if one of the lowest three scores'.

Eventually, the 1- and 5-min scores became standard. She then applied them to assess the effects of labour, delivery and maternal anaesthetics on the baby. She was aided by Duncan Holaday, who measured blood gases, blood levels of anaesthetics and $\mathrm{pH}$, and by Stan James, a paediatrician [7]. They discovered that the basic problems were hypoxia and acidosis in babies with low scores [8].

The score, she hoped, would hasten the recognition of asphyxia and thereby provide for rapid resuscitation. She also hoped to eliminate unnecessary interventions in the healthy baby.

The prediction of late neurological outcome was implicit, but not specifically planned. The Apgar 5-min score was used to be a predictor of survival and of neurological development [9]. Although the score has proved a great success as a descriptor of clinical condition at specific time intervals, it does not reliably predict survival, neurological handicap, or death of the individual neonate [10]. But it does provide scores for related functional categories. It has emerged as an invaluable test, but a low Apgar score is not diagnostic of perinatal asphyxia or cerebral handicap, and a high score does not guarantee the ultimate quality of neurological function.

Apgar also was the first to catheterize the newborn's umbilical artery to measure venous pressure, and to catheterize the right atrium through the umbilical vein to assess the effects of maternal anaesthetics on the baby. She found cyclopropane to be more depressant than other agents, and its use quickly declined.

In 1959, she took sabbatical leave at Johns Hopkins University to get a master of public health degree. In June 1959, she left anaesthesia to become director of the National Foundation's (previously the March of Dimes) new division of congenital defects. She was enormously successful: travelling around the world, lecturing and tirelessly raising funds for birth defects. It was said that

'Virginia Apgar probably did more than any other physician to bring the problem of birth defects out of the back rooms'.

She was a keen stamp collector, but her greatest interest was music [11]. An accomplished cellist and violinist, she made her own instruments.

In 1959, she was made Professor of Paediatrics at Cornell University. In 1961 she received the Distinguished Service Award from the American Society of Anesthesiologists, and in 1973 she was the first woman to receive 


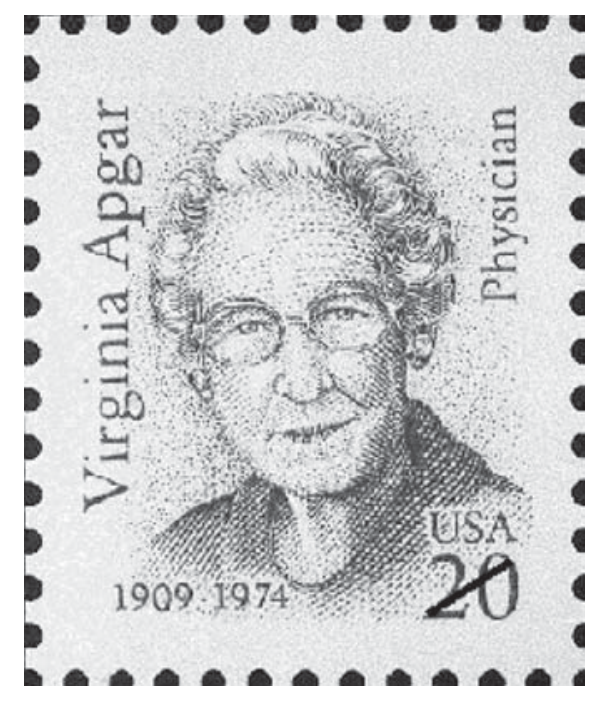

the Gold Medal for Distinguished Achievement in Medicine from the College of Physicians and Surgeons, Columbia University. She died in 1974, aged 65, in New York.

To honour her, the U.S. Postal Office issued a 20 cent commemorative stamp (fig. 1) on October 24th, 1994. (Stamp collecting was another of her hobbies.) In November of 1995, she was inducted into the National Women's Hall of Fame in New York.

Fig. 1. Dr. Virginia Apgar.

\section{References}

1 Butterfield LJ: Virginia Apgar, MD, MPhH. Neonatal Netw 1994;13:81-83.

2 Calmes SH: Virginia Apgar: a woman physician's career in a developing specialty. J Am Med Womens Assoc 1984;39:184-188.

3 Calmes SH: American anesthesia from 19201950: was it women's work? Annu Meet Am Assoc for the History of Medicine, San Francisco, May 1984.

4 Keys T: The History of Surgical Anesthesia. Huntington, Kneger, 1978.
5 Apgar V: Proposal for a new method of evaluation of the newborn infant. Curr Res Anesth Analg 1953;32:260-267.

6 Finster M, Wood M: The Apgar score has survived the test of time. Anesthesiology 2005; 102:855-857.

7 James LW: Memories of Virginia Apgar. Teratology 1974;10:213-215.

8 Apgar V, Holaday DA, James LS, et al: Evaluation of the newborn infant: second report. J Am Med Assoc 1958;168:1985-1988.
9 Drage JS, Kennedy C, Schwartz BK: The Apgar Score as an index of neonatal mortality. Obstet Gynecol 1964;24:222.

10 Ruth VJ, Raivio KO: Perinatal brain damage: predictive value of metabolic acidosis and the Apgar score. BMJ 1988;297:24-27.

11 Goodwin JW: A personal recollection of Virginia Apgar. J Obstet Gynaecol Can 2002;24: 248-249. 